\section{ISSN 1991- 8690}

website :http:// jsci.utq.edu.iq

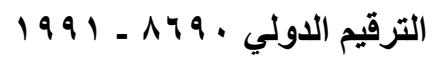

Email: utjsci@utq.edu.iq

\title{
Determination of trace metals in hair samples of Iraqis people living in suburban and urban in Basrah governate, southern of Iraq
}

\author{
Abdullah Y. Khudhair.
}

College of Pharmacy . Medicinal branch.

\section{$\underline{\text { Abstract }}$}

This study was carried out on human hair samples that were collected from different areas of Basrah Governorate in the year 2009, (67 people of both genders). In the year 2010 (17 people of both genders. The two groups were divided into seven subgroups according to their age. Hair was analyzed for $\mathrm{Na}, \mathrm{K}, \mathrm{Ca}, \mathrm{Mg}, \mathrm{Hg}, \mathrm{Pb}, \mathrm{Cd}, \mathrm{U}, \mathrm{Co} \mathrm{Cu}, \mathrm{As}, \mathrm{Fe}, \mathrm{Al}$ and $\mathrm{Zn}$; using ICP/Ms instrumentation at maxxam analytical INC, Canada. The results showed levels of most essential and heavy metals that were tested in the year 2009, and the metals tested in the year 2010 were higher than international levels. A significant difference have been observed $\mathrm{P}<0.05$ between the same group according to the age criteria. Significant differences were observed in between subgroups of the year 2009 Vs. 2010. The maximum reading of $\mathrm{Hg}$, $\mathrm{Pb}, \mathrm{U}, \mathrm{Cu}, \mathrm{Ca}, \mathrm{Mg}$, As and Co was found in subgroup (2), Fe and $\mathrm{Zn}$ in subgroups 4, 5 and 6 respectively for 2009. Samples from 2010, showed the maximum reading of $\mathrm{Hg}, \mathrm{Pb}, \mathrm{Cd}, \mathrm{Cu}, \mathrm{Zn}, \mathrm{Ca}$, and $\mathrm{Co}$ found in subgroup(3), whereas $\mathrm{Fe}$, $\mathrm{Mg}, \mathrm{Al}$, and As, levels were high levels in subgroups 1,2 and 4. The high level of heavy metals seen in this study, reveals that these areas where samples were collected from are highly contaminated with these toxic and polluted materials. This high level needs intensive care from the government to protect the environment from these toxic and carcinogenic substances. Also, the existence of Uranium in the samples that were analysis need special care from decision makers due to the potential harm that could be caused by these metals to public welfare.

Key words:Toxic elements, heavy metals, Uranium, essential elements .hair sample.

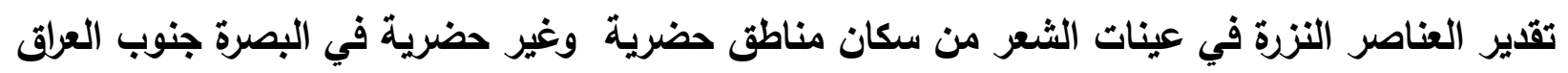

$$
\text { كلية الصيدلة - فرع الادوية - جامعة البصرة خضير }
$$

\footnotetext{
المستخلص

أجريت هذه الدراسة على عينات من الثعر جمعت من مناطق مختلفة من محافظة البصرة الحضرية وغير الحضرية للعام 9. . ب و كان عدد

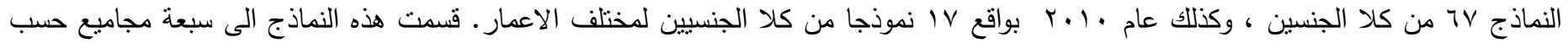

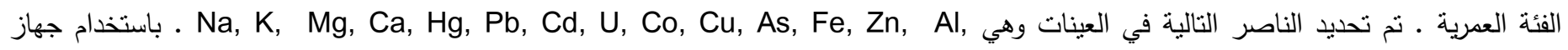
ICP/Ms

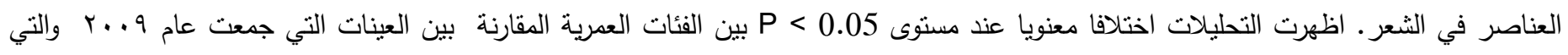
جمعت في • ا • ب والتي اظهرت ارتفاع في الزئبق والرصاص و اليورانيوم والنحاس و الكالسيوم و المغنسيوم و الكوبلت في المجموعة الثانية والحديد والزئبق

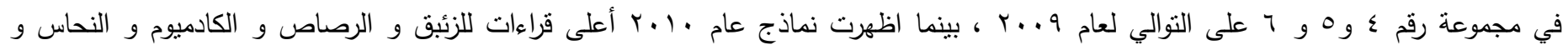

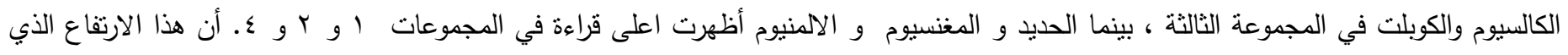

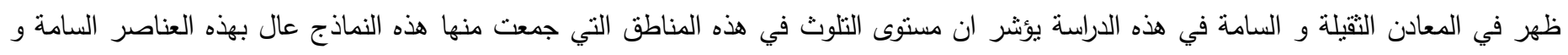

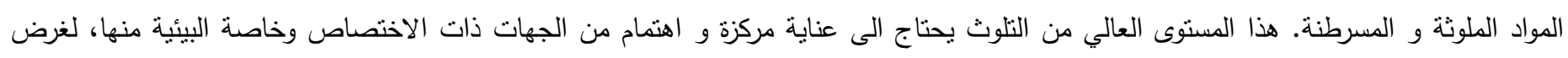
حماية البيئة من هذه المواد السامة والمسرطنة ـ كذللك ظهور عنصر اليورانيوم في هذه النماذج المختلفة تحتاج الى عناية خاصة لغرض الحماية من هذه الهن العناصر الخطيرة. الكلمات المفتاحية : عناصر سامة، عناصر ثقيلة ، اليورانيوم، عناصر أساسية ، نماذج شعر • تلوث
} 


\section{Introduction}

Pollution is any substance in the environment, which causes objectionable effects, impairing the welfare of the environment, reducing the quality of life and may eventually cause death (Duruibe et. al.2007). Metals occur naturally in the earth crust, and their content in the environment can vary between different regions leading to regional variation of background concentration. The distribution of metals in the environment is affected, controlled by the properties of metals and influences of environmental factors (Khalifi and Hamza-Chaffai 2010). Heavy metals is generic term for metallic elements having atomic weight higher than 40.40 (Ming-Ho 2005). Heavy metals enter the environment in two ways natural and atmospheric. Natural weathering of earth crust, mining, soil erosion, industrial discharges, Urban runoff sewage discharges, pesticides or diseases control agents applied to plants, air pollution fallout and number of other products such as industrial waste, the collateral effect of war, oil refineries, and the petro-chemist industries waste product; (Ming-Ho 2005; Morais et,al,2011).Out of 92 naturally occurring elements, approximately 30 metals and metalloids are potentially toxic to human, such as, $\mathrm{Li}, \mathrm{Al}, \mathrm{Ti}, \mathrm{V}, \mathrm{Cr}, \mathrm{Mn}, \mathrm{Co}, \mathrm{Ni}, \mathrm{Cu}, \mathrm{As}, \mathrm{Se}, \mathrm{Pb}, \mathrm{Ag}, \mathrm{Cd}$, $\mathrm{Sn}, \mathrm{Te}, \mathrm{Cs}, \mathrm{Ba}, \mathrm{Pt}, \mathrm{Hg}, \mathrm{U}, \mathrm{Bi}$, and others. Some individuals are primarily exposed to these contaminants in the work place .For most people, the main method of exposure to these toxic elements is through diet (food and water). The contamination chain of heavy metals almost always follows a cyclic order, industry, atmosphere soil, water food and human. The toxicity and the resulting threat to human's health of any contaminants is a function of concentration. It is well known that chronic exposure to heavy metals and metalloids at relatively low level can cause adverse effects (Agency for toxic substance and disease registry 2007; 2008 (ATSDR). The potential pathogenic and toxic effects of continuous low-level exposure to metals, is becoming more of a concern to researchers. Such phenomenon is attracting more studies and researches to address this topic. Hair has the potential of being an excellent bio-monitor, due its historical representation of intake over prior time. Using hair as a tool, we began to collect samples to investigate the exposure of population to toxic and pollutant substances. The analysis of hair for metals content reflects environmental exposure (to the pollutants substances (Srogi, 2004; Harkins and Susten,2003; Pereiraab, et.at. 2004; Amortey et.al.2011; Khudzari, et.al. 2011), and good estimate of contamination level in the environment of the environmental contamination. It was shown in many studies that there is a positive correlation between soil, water, air content, and the internal content of metals in the hair of exposed population (Christopher, et.al.2009; Chlopick,et. al.1998)For most metals their accumulation in the hair reflect the accumulation in the whole body (Christopher,et.al. 2009; Hassan, et. al. 2006), with exception of magnesium and zinc, where the accumulation in hair may be present in the follicular cells as enzyme cofactors, or toxic elements, poorly handled by renal excretion, which are dumped into the hair as part of a detoxification mechanism (Erten et. Al. 1978). On the other hand, most heavy metals $\mathrm{Cd}$, Cr, $\mathrm{Ni}$, and $\mathrm{Pb}$ have higher concentration in hair than other body parts which can help in the analytical process( Chlopicka et.al. 1998). Metals and metalloids can enter human body, in several ways, such as dispersion on soil, directly through inhalation, and ingestion, through the drinking water and via consumption of vegetables themselves with high metals content, in addition to fish meat that found in contaminated water.Environmental contamination with heavy metals is one of the collateral effect of war, industrial planets, oil refineries or the petrochemical waste product, sewages effluent in rivers. e.c.t . There were so many attempts to study the effect of heavy metals and the pollutants metals in the southern of Iraq especially at Basrah Governorate Postfirst and second gulf wars, after the evacuation of Iraqi troops from Kuwait by international alliance led by American troops. Unfortunately, all the attempts were not successful to assess the real level of trace metals, due to the lack of advanced instruments at the researches laboratories in the Universities and other organizations. In addition, after the year 2003, following the occupation of American alliances, there was another attempt by Iraqi researchers to study the different levels of pollutants heavy metals ( AlImarah,et.al.2010; Karabedian ,et.al.2009; Al-Imarah, et.al. 2007). On the other hand, Fido and Al-Saad, (2005 have found that in both normal and autism boys "autistic children" in Kuwait showed high levels of toxic metals in their hair such as antimony, Uranium, arsenic, beryllium, mercury, lead and aluminum. Also, Al-Imarah, et.al.( 2010) found in the area where study carried out, high levels of $\mathrm{Pb}, \mathrm{As}, \mathrm{Cd}$ and $\mathrm{Hg}$ in both hair, and water samples. On the other hand, systemic deficiencies of $\mathrm{Mg}, \mathrm{Zn},, \mathrm{Cr}, \mathrm{Mn}$, or $\mathrm{Cu}$ will be reflected low hair concentration of these elements. Toxic level of nutritionally important minerals will also 
be found in high concentration in the hair (Davies, 1982). There is reasonable concern to investigate, if there is contamination by metals due to its negative effects on population health, especially children. In order to develop modalities to support people that live in post-war, we need a sufficient practical knowledge on the level of pollution in these regions. Furthermore, due the insufficient information concern the level of

\section{Material $s$ and methods}

In the year 2009, hair samples were collected from 67 individuals from both genders, males and females, from different areas, Al-Shafie suburban , and urban center (Al-Saaie sector and Al-Tanuma) of basrah Governorate. The age range span from less than 1 year to over 60 years old. Using stainless steel scissors, hair sample were collected from symmetrical occipital region as close as possible to the scalp. On the nape of the neck, the nearest $2-3 \mathrm{~cm}$ from skin, and considering an average growth rate of hair between 0.6 and $3.6 \mathrm{~cm}$ per month. The hair sample immediately placed in sealed plastic bag and stored in clean places till the analysis performed. All the information about the gender, age, and general health condition was put on the sample bag label. These samples were analyzed in the year 2009, at Maxxam analytical INC. in Ontario, Canada. Also, (in the year 2010) hair sample were collected from another population sample that consisted of 17 mixed groups of both genders, males and females, that occupied the same area. Analysis of hair sample for trace and heavy metals carried out at maxxam analytical INC. in Canada using the multiple elemental analysis instrument ICP/MS (Inductivity coupled plasma mass spectrometry), in a fully control environment and method used by the company. Samples that obtained from the participants of age less than 18 years, we obtained a consent from their guardian. The samples collected in 2009 were divided into seven groups according to the age of participants as contamination in soil and plants by heavy and trace metals (Salman, 2011), as it has been recommended by environmental protection Agency (EPA) and international atomic energy agency (IAEA)that the use of hair as an important biological tool for worldwide environmental monitoring(IAEA, 1994), therefore, we conducted directly the population in taking hair samples from inhabitants area.

follow. Group one $(\mathrm{N} 1=8)$ from 6 month -9 year; group two $(\mathrm{N} 2=23), 10-19$ years; group three $(\mathrm{N} 3=$ 10), 20 - 29 year; group four $(\mathrm{N} 4=5), 30-39$ years; group five $(\mathrm{N} 5=10), 40-49$ years; group six $(\mathrm{N} 6=7)$ $50-59$ years; group seven $\mathrm{N} 7=4,60$ years and over. Also samples collect in 2010 were separated into six groups according to the age of volunteer as: group $1(\mathrm{~N} 1=3), 0-9$ years; group two $(\mathrm{N} 2=2), 20-29$ year; group three $(\mathrm{N} 3=4), 30-39$ years; group four (N4=2),40 -49 years; group five (N5=2), 50-59 : group six $(\mathrm{N} 6=4), 60$ year and over.

\section{Analysis of Samples}

All samples were analyzed for heavy metals The essential difference in the concentration of metals in hair samples of different groups of age, were calculated using two way analysis of variance (INOVA) where Pvalues are considered significant at level lower than 0.05 limit interval. 
Table 1: Reference intervals for hair elements in microgram/gram of hair( Erten et.al.1978, /Biolab medical Unit, nutritional and environmental medicine -London, 2010

\begin{tabular}{|c|c|c|}
\hline Element & $\begin{array}{l}\text { Reference } \\
\text { interval } \mu \mathrm{g} / \mathrm{g}\end{array}$ & Comments \\
\hline $\mathrm{Ca}$ & $200-2800$ & $\begin{array}{l}\text { Hair calcium levels are affected by PTH secretion and bone turnover, } \\
\text { including periodontal disease as well as by ingestion of hard water. High } \\
\text { hair Ca and Mg can be indicator that hair treatment(eg bleaching and } \\
\text { perming ) have been used by patients within three month before hair } \\
\text { sampling. }\end{array}$ \\
\hline $\mathrm{Cr}$ & $0.1-1.50$ & Result can be used to assess chromium status. \\
\hline Co & $0.01-0.20$ & Reflect B12 status as well as cobalt exposure. \\
\hline $\mathrm{Cu}$ & $10-100$ & $\begin{array}{l}\text { Low level reflect copper deficiency; hair copper is increased in high } \\
\text { estrogen state, Zinc/ copper ratio change in malignancy. }\end{array}$ \\
\hline Fe Iron & $5.0-30.00$ & $\begin{array}{l}\text { Reflect whole blood concentration, but is not a good test of iron } \\
\text { deficiency ( which should be investigated by serum analysis. }\end{array}$ \\
\hline $\begin{array}{c}\text { Mn } \\
\text { manganese }\end{array}$ & $0.2-2.00$ & $\begin{array}{l}\text { High level reflect manganese intoxication, low level are often found in } \\
\text { epilepsy, hyperactivity and neurological disorder. }\end{array}$ \\
\hline $\begin{array}{c}\mathrm{Mg} \\
\text { magnesium }\end{array}$ & $60-160$ & $\begin{array}{l}\text { Low level reflect tissue de-saturation of magnesium ; high levels are } \\
\text { caused by increased ingestion or exposure. }\end{array}$ \\
\hline $\mathrm{P}$ & $100-200$ & Reflect bone turnover and PTH secretion. \\
\hline K potassium & $50-300$ & $\begin{array}{l}\text { High hair potassium has been reported in coeliac disease; low level may } \\
\text { result from alcohol abuse. Plasma K should be used to assess current } \\
\text { status and treatment. }\end{array}$ \\
\hline Se Selenium & $0.4-2.00$ & $\begin{array}{l}\text { Low hair selenium is an indicator of poor prognosis in a variety of } \\
\text { condition; high levels reflect selenium intake as well as selenium- } \\
\text { containing anti- dandruff shampoo. }\end{array}$ \\
\hline Na Sodium & $50-1000$ & $\begin{array}{l}\begin{array}{l}\text { Sodium level above this range usually reflect exposure to certain } \\
\text { shampoo. }\end{array} \\
\end{array}$ \\
\hline Zn Zinc & $160-240$ & $\begin{array}{l}\text { Low hair zinc reflect poor intake and } \mathrm{Zn} \text { unavailability as an enzyme co- } \\
\text { factor. High hair } \mathrm{Zn} \text { can paradoxically be caused by slow hair growth as a } \\
\text { result of inadequate } \mathrm{Zn} \text { status, thereby allowing more time for low level s } \\
\text { of } \mathrm{Zn} \text { to be incorporated in the hair shaft. High hair } \mathrm{Zn} \text { can also be a sign } \\
\text { of use of } \mathrm{Zn} \text { Pyrithione- containing anti-dandruff shampoo. }\end{array}$ \\
\hline Al Aluminum & $<50.00$ & $\begin{array}{l}\text { Much investigated for possible correlation with CNS symptom, } \\
\text { especially in ageing subject. May come from acidic food cooked in } \\
\text { aluminum pots. }\end{array}$ \\
\hline As arsenic & $<1.00$ & $\begin{array}{l}\text { Elevated levels reflect increased arsenic exposure from drinking water, } \\
\text { alcohol, beverages, shellfish or contact with treated wood and pesticides. }\end{array}$ \\
\hline Cd cadmium & $<0.10$ & $\begin{array}{l}\text { From exposure to smoke and tobacco, but also } \mathrm{Ni} / \mathrm{Cd} \text { batteries, PVC } \\
\text { plastic (yellow color ), motor exhausts, sludge and fertilizers. }\end{array}$ \\
\hline $\mathrm{Pb}$ Lead & $<2.00$ & $\begin{array}{l}\text { A useful measure of lead exposure ; hair represents a detoxification } \\
\text { pathway for lead keeping the body burden at lower level. }\end{array}$ \\
\hline Hg Mercury & $<1.00$ & $\begin{array}{l}\text { High hair Hg result from leaking dental amalgams, consumption of } \\
\text { contaminated fish and other sources. Hair mercury reflect body burden of } \\
\text { organic mercury and is much studied as a medium for assessing exposure. }\end{array}$ \\
\hline Ni Nickel & $<1.40$ & $\begin{array}{l}\text { From jewelry, stainless steel, dental crown and a variety of industrial } \\
\text { sources. }\end{array}$ \\
\hline
\end{tabular}




\section{Results}

The mean represents the total sample of 67 both male and female. The maximum and minimum values represent the number within the group of age showed in parenthesis.

Table 2 shows the international level of elements $(\mu \mathrm{g} / \mathrm{g}$ Hair) and that measured in this study (mg/kg Hair) 2009 samples

\begin{tabular}{|l|l|l|l|l|l|l||}
\hline Element & $\begin{array}{l}\text { INT level } \\
\mu g / g\end{array}$ & $\begin{array}{l}\text { No. } \\
\text { above } \\
\text { normal }\end{array}$ & $\begin{array}{l}\text { Minimum } \\
\mathrm{mg} / \mathrm{kg}\end{array}$ & $\begin{array}{l}\text { Maximum } \\
\mathrm{Mg} / \mathrm{kg}\end{array}$ & $\begin{array}{l}\% \\
\text { increased }\end{array}$ & Mean \pm Se \\
\hline $\mathrm{Na}$ & $50-1000$ & 60 & $135.94(5)$ & $6524.58(2)$ & 85.8 & $1308.42 \pm 637.91$ \\
\hline $\mathrm{K}$ & $50-300$ & 60 & $2.28(1)$ & $3018.00(2)$ & 85.8 & $878.07 \pm 350.53$ \\
\hline $\mathrm{Hg}$ & $<1.00$ & 58 & $0.00(2)$ & $12.40(3)$ & 86.6 & $1.431 \pm 0.556$ \\
\hline $\mathrm{U}^{238}$ & --- & $-\cdots-$. & $0.02(2)$ & $0.34(2)$ & - & $0.138 \pm 0.054$ \\
\hline $\mathrm{Cd}$ & $<0.1$ & 38 & $0.00(3)$ & $0.5(6)$ & 58.19 & $0.0515 \pm 0.011$ \\
\hline $\mathrm{Pb}$ & $<2.00$ & 58 & $.32(3)$ & $70.53(2)$ & 86.6 & $3.605 \pm 0.768$ \\
\hline $\mathrm{Cu}$ & $10-100$ &.-- & $0.21((2)$ & $26.05(2)$ & - & $8.555 \pm 1.375$ \\
\hline $\mathrm{Fe}$ & $5.0-30.0$ & 53 & $10.22(2)$ & $4079(4)$ & 79.1 & $129.587 \pm 52.21$ \\
\hline $\mathrm{Zn}$ & $160-240$ & 43 & $1.69(1)$ & $4231.24(5)$ & 64.1 & $293.94 \pm 92.85$ \\
\hline $\mathrm{Ca}$ & $200-2800$ & 6 & $401.97(6)$ & $10824.83(2)$ & 9 & $2058.72 \pm 936.16$ \\
\hline $\mathrm{Mg}$ & $60-160$ & 61 & $40.86(1)$ & $2073.44(2)$ & 91 & $514.97 \pm 135.170$ \\
\hline $\mathrm{Al}$ & $<50$ & 58 & $0.08(2)$ & $672.07(2)$ & 86.6 & $32.81 \pm 9.79$ \\
\hline $\mathrm{As}$ & $<1.00$ & -- & $0.00(2)$ & $0.50(2)$ & - & $0.0788 \pm 0.0291$ \\
\hline $\mathrm{Co}$ & $0.01-0.20$ & 2 & $0.00(2)$ & $0.85(2)$ & 2.69 & $0.05 \pm 0.01$ \\
\hline
\end{tabular}

The mean represent the total sample of 17 of both gender. The Maximum and minimum represent the number within the group of age (2010) in parenthesis.

Table 3 shows the international level of elements $(\mu \mathrm{g} / \mathrm{g}$ Hair) and that measured in this study (mg/kg Hair) 2010 sample

\begin{tabular}{|c|c|c|c|c|}
\hline Element & Int Level & Minimum & Maximum & Mean $\pm \mathrm{Se}$ \\
\hline $\mathrm{Na}$ & $50-1000$ & $236.27(3)$ & $1886.79(6)$ & $639.08 \pm 106.53$ \\
\hline $\mathrm{K}$ & $50-300$ & $55.03(6)$ & $1384.35(6)$ & $378.32 \pm 83.06$ \\
\hline $\mathrm{Hg}$ & $<1.00$ & $0.8 \quad(3)$ & $61.91 \quad$ (3) & $12.52 \pm 5.24$ \\
\hline $\mathrm{U}$ & $\cdots$ & 0.02 (1) & $\begin{array}{ll}0.63 & (5)\end{array}$ & $0.164 \pm 0.02$ \\
\hline $\mathrm{Cd}$ & $<0.1$ & $0.01 \quad(6)$ & 0.36 & $0.104 \pm 0.04$ \\
\hline $\mathrm{Pb}$ & $<2.00$ & $0.45 \quad(6)$ & 12.52 (1) & $3.90 \pm 0.92$ \\
\hline $\mathrm{Cu}$ & $10-100$ & $6.76 \quad$ (3) & $45.35 \quad(3)$ & $21.97 \pm 2.66$ \\
\hline $\mathrm{Fe}$ & $5.0-30.0$ & $23.5 \quad(5)$ & $102.88(2)$ & $59.57 \pm 6.89$ \\
\hline $\mathrm{Zn}$ & $160-240$ & $119.56(6)$ & $2084.70(3)$ & $393.43 \pm 117.92$ \\
\hline $\mathrm{Ca}$ & $200-2800$ & $915.8(6)$ & $7913.20(3)$ & $3340.54 \pm 534.53$ \\
\hline $\mathrm{Mg}$ & $60-160$ & $138.36(1)$ & $1546.73(2)$ & $646.34 \pm 116.51$ \\
\hline $\mathrm{Al}$ & $<50.00$ & $11.76(5)$ & $52.00 \quad(1)$ & $29.58 \pm 2.81$ \\
\hline As & $<1.00$ & $.04 \quad(6)$ & $0.22 \quad$ (1) & $0.088 \pm 0.01$ \\
\hline $\mathrm{Co}$ & $0.01-0.2$ & $0.01(6)$ & $0.62(3)$ & $0.14 \pm 0.03$ \\
\hline
\end{tabular}

The elements $\mathrm{Na}, \mathrm{K}, \mathrm{Hg}, \mathrm{Pb}, \mathrm{Cu}, \mathrm{Ca}, \mathrm{Mg}, \mathrm{Al}, \mathrm{Si}, \mathrm{As}$, and Co were analysis in 2009 did not show a significant differences in between groups of ages. While Uranium and other metals showed a significant difference between the groups, when the multiple comparison in between the groups are applied as in following table 4 .
Table 4, showed multi comparison in between subgroups of the same group of the following element, $\mathrm{U}, \mathrm{Cd}, \mathrm{Fe}$ and

$$
\mathrm{Zn}
$$

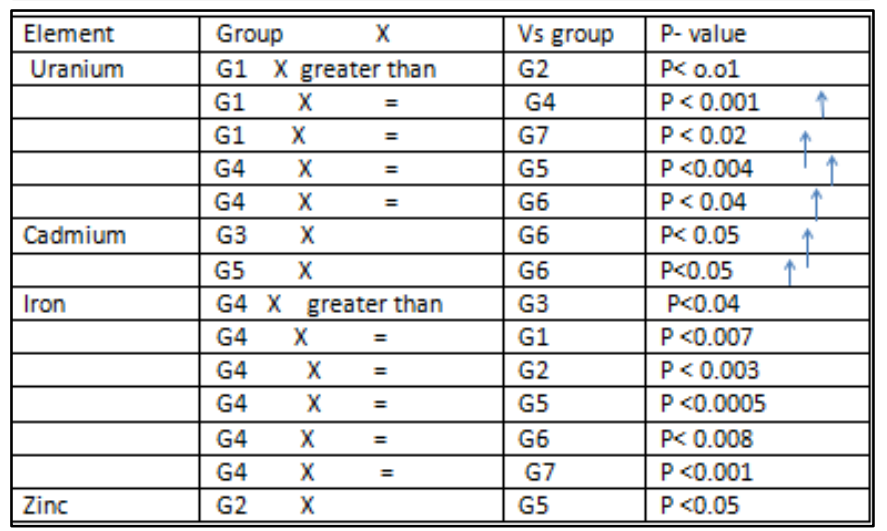

A multiple comparison were also applied between groups analyzed in 2009 and that analysis in 2010,the significant difference appear as follow in between the groups as in table 5 .

Table 5 A multiple comparison between groups 2009 and those of 2010 for $\mathrm{Hg}$. N- number of individual samples analvzed are in parenthesis

\begin{tabular}{|c|c|c|c|}
\hline Element & Group 2009 & Group 2010 & $p$-value \\
\hline $\mathrm{Hg}$ & G1 1.0925 & $\begin{array}{lll}\text { G3 } & 24.4200^{4}\end{array}$ & $P<0.001$ \\
\hline & (8) & G4 $31.2400(2)$ & $P<0.001$ \\
\hline & $\overline{\mathrm{G} 1}$ & $\begin{array}{lll}\text { G5 } & 19.1800 \quad \text { (2) }\end{array}$ & $P<0.03$ \\
\hline & (10) & G3 24.2400 (4) & $P<0.001$ \\
\hline & $(10)$ & G4 $31.2400 \quad(2)$ & $P<0.001$ \\
\hline & G3 $\quad(10)$ & G5 $19.1800 \quad(2)$ & $P<0.03$ \\
\hline & G4 $1.7040 \quad$ (5) & G4 $31.2400 \quad(2)$ & $P<0.001$ \\
\hline & G4 & G5 19.1800 (2) & $P<0.001$ \\
\hline & G5 ${ }^{1.2047}(10)$ & G4 $31.2400 \quad(2)$ & $P<0.001$ \\
\hline & G6 $\quad .6703 \quad(7)$ & G4 $31.2400(2)$ & P 0.002 \\
\hline & G7 $\quad 8925$ & G4 $31.240 \quad(2)$ & $P<0.002$ \\
\hline
\end{tabular}

Mercury concentration in between the age groups of the same year that was analyzed in either 2009 or 2010 are not show any different levels. Whereas the $\mathrm{Hg}$ in samples analyzed in 2010 mostly are high levels than that of 2009. The level of $\mathrm{Hg}$ in both samples analyzed are greater than that of international reference Mentioned by Erten et.al.1978; Bio lab medical unit London- England 2011 . The high level of mercury appears in G4(30-39 years old, followed by $20-29$ years old table5).In case of Uranium, the samples analyzed in 2009, the concentration has shown significant difference $\mathrm{P}<0.01$ in between G1 vs G2 ; G1 Vs G4 P <0.001; G1 vs G7 P $<0.02$ and G4 vs G5 $\mathrm{p}<0.019 ; \mathrm{G} 4$ vs G6 $\mathrm{P}<0.04$. Also, the different age 
groups for samples analyzed in 2010, showed a significant difference as: G1 vs G2 P <0.015; G1 vs G4 $\mathrm{P}<0.05 ; \mathrm{G} 1$ vs g5 p < $0.00001 ; \mathrm{G} 2$ vs G5 P <0.05; G2 vs G6 P < 0.03; G3 vs G5 P <0.001; G4 vs G5 P < 0.017; and G5 vs G6 P < 0.001.The higher level of uranium appear in group 4(30-39 years old for sample 2009; while in samples of 2010 the higher level appeared in group $50.63 \mathrm{ppm}, 50-59$ years ,followed by group 3 of $20-29$ years old. The cadmium concentration did not show any differences in between the age groups that analyzed in 2009, only in G6 Vs G5 $\mathrm{P}<0.05$.The samples analyzed in 2010, also, cadmium showed significant difference in between G3 vs G5 P < 0.035 and G3 vs G6 P <0.013.The high level observed $0.50 \mathrm{ppm}$ in group 6 that analyzed in 2009, and group 3 $0.36 \mathrm{ppm}$ in samples analyzed in 2010. The lead and copper did not show any differences in between age groups that analyzed in 2009. Whereas, $\mathrm{Pb}$ show significant difference in between group analyzed in 2010 as G1 vs G6 P <0.02 and G3 vs G6 P $<0.03$. The iron which is essential element for $\mathrm{Hb}$, show significant difference between samples groups analyzed in2009, in which G4 showed high level of iron $\mathrm{P}<0.01$ compared with the other groups of ages. On the other hand, iron have not shown any differences between the groups that analyzed in 2010.Zinc which is important element for enzymatic reaction as co-factor, showed significant difference between G1 vs G5 P $<0.07$ and G2 Vs G5 p< 0.05 in samples analyzed in 2009, whereas in samples analyzed in 2010 Zinc show a difference between G1 and G3 P $<0.03$ only. The calcium is an important element in the bone metabolism, blood clotting, and have positive relationship with PTH Secretion, showed significant elevated level between G1 vs G3 P < 0.004, also G3 has greater level than both G2, G5, and G6, (P <0.01, P < 0.014 and $p<0.02$ respectively) in samples analyzed in 2010. Calcium, Mg, Al, As, and Co did not show any differences in between the groups. Magnesium, Aluminum and cobalt have little difference between some groups that analyzed in 2010, especially between G1 and G3; G1 and G6; and G3 vs G6 P <0.001. The multi comparison for uranium concentration in between groups analyzed in 2009 and those analyzed in 2010, the differences were appeared in between the group as in table 6 .
Table 6 Multi comparison between groups analyzed in 2009 and 2010 for uranium

\begin{tabular}{|c|c|c|c|c|}
\hline Uranium & 2009 & 2010 & P-Value & \\
\hline & G1 less than & $\mathrm{G} 2$ & $P<0.02$ & More \\
\hline & $\mathrm{G} 1=$ & G5 & $P<0.0001$ & $=$ \\
\hline & G3 more than & G5 & $P<0.0001$ & Less \\
\hline & $\mathrm{G} 4=$ & G1 & $P<0.008$ & Less \\
\hline & G4 & G5 & $P<0.01$ & Less \\
\hline & G4 & G6 & $P<0.01$ & Less \\
\hline & G5 & G2 & $P<0.04$ & Less \\
\hline & $\mathrm{G} 5=$ & G5 & $P<0.001$ & Less \\
\hline & G6 less than & G5 & $P<0.0001$ & More \\
\hline & G7 more than & G5 & $P<0.003$ & Less \\
\hline & G1 less than & G3 & $P<0.01$ & More \\
\hline & G3 more than & G1 & $P<0.03$ & Less \\
\hline & G3 less than & G3 & $P<0.0001$ & More \\
\hline & G4 more than & G3 & $P<0.001$ & Less \\
\hline & G6 less than & G3 & $P<0.04$ & More \\
\hline & G7 more than & G3 & $P<0.002$ & Less \\
\hline & $\mathrm{G} 5=$ & G1 & $P<0.003$ & Less \\
\hline & $\mathrm{G} 7=$ & G1 & $P<0.04$ & Less \\
\hline
\end{tabular}

The multi comparison for lead concentration in between groups analyzed in 2009 and those analyzed in 2010, show the following: G1 for 2009 , vis all group 2010 no differences appeared in between the groups, whereas G1 for 2010 is higher Vis all groups of $2009 \mathrm{P}<0.01$. G3 for 2009 vs all groups of 2010 did not show significant difference only that with G4 $\mathrm{P}<0.005$. There is no apparent difference in between G2 for 2010 vis all groups of 2009. Whereas G3 of 2010 vis G3, G5,G6 and $G 7$ of 2009 show significant different $P<0.01$. The lead as carcinogenic and poisoning metals show higher level than that of international value, where was 12.26 and 12.52 in group one and three for sample2010 and $11.48 \mathrm{ppm}$ and $70.53 \mathrm{ppm}$ in groups one and two of samples 2009, compared with international level less than $2.00 \mathrm{ug} / \mathrm{g}$.In case of copper, which essential element in myoglobin, the multiple comparison between groups analyzed in 2009 and 2010 show the following differences as in table 7.

Table 7 Shows multiple comparison between samples analyzed in 2009 and 2010 for the copper, values are in

\begin{tabular}{|c|c|c|c|c|c|}
\hline Copper & 2009 & 2010 & & $\mathrm{P}$-value & \\
\hline & G1 less & All group & $p>14.915$ & $P<0.05$ & Less \\
\hline & All group $<9.3117$ & G1 & 20.8233 & $P<0.05$ & Less \\
\hline & \begin{tabular}{|l|l|} 
G3 & 8.188 \\
\end{tabular} & All grour & ps $>14.915$ & $P<0.005$ & Less \\
\hline & $\mathrm{G} 4, \mathrm{G} 5, \mathrm{G} 6, \mathrm{G} 7<9.31$ & G2 & 22.9255 & $P<0.0005$ & Less \\
\hline & $\begin{array}{ll}\text { G4 } & 8.68 \\
\end{array}$ & G5 & 31.25 & $P<0.001$ & Less \\
\hline & All groups < 19.311 & G3 & 27.92 & $P<0.001$ & Less \\
\hline & $\begin{array}{ll}\text { G5 } & 7.897 \\
\end{array}$ & $\mathrm{G} 5, \mathrm{G} 6$ & $>14.915$ & $P<0.0001$ & Less \\
\hline & All groups < 9.311 & G4 & 14.915 & N.S & -- \\
\hline & $\begin{array}{ll}\text { G6 } & 8.9743 \\
\end{array}$ & G5 & 31.250 & $P<0.001$ & Less \\
\hline & All group & G5 & 31.250 & $P<0.0001$ & Less \\
\hline
\end{tabular}


2009 No. of samples for total mean (67) ,2010 No of samples for total mean(17). The number in parenthesis represent the group number.

Table 8 show the mean of total group in both 2009 \& 2010 , and the maximum and the minimum value elements appear in individual group of sample tested, values are in ppm 2009 $-2010-$

\begin{tabular}{|l|l|l|l|l|l|l|}
\hline Element & Mean & Maxi. & Minim. & Mean & Maxi. & Minim \\
\hline $\mathrm{Na}$ & 1308.42 & $6524.58(2)$ & $135.94(5)$ & 639.08 & $1886.79(6)$ & $236.27(3)$ \\
\hline $\mathrm{K}$ & 878.07 & $30193.0(2)$ & $2.28(1)$ & 378.32 & $1384.35(6)$ & $55.03(6)$ \\
\hline $\mathrm{Hg}$ & 1.43 & $12.40(3)$ & $0.00(2)$ & 12.56 & $61.97(3)$ & $(0.80(3)$ \\
\hline $\mathrm{U}$ & 0.14 & $0.34(2)$ & $0.02(1,2)$ & 0.16 & $0.63(4)$ & $0.02(1)$ \\
\hline $\mathrm{Cd}$ & 0.05 & $0.50(6)$ & $0.00(3)$ & 0.11 & $0.36(3)$ & $0.01(6)$ \\
\hline $\mathrm{Pb}$ & 3.61 & $70.53(2)$ & $0.21(2)$ & 3.90 & $12.52(3)$ & $0.45(6)$ \\
\hline $\mathrm{Cu}$ & 8.555 & $26.05(2)$ & $0.21(2)$ & 21.97 & $45.53(3)$ & $6.76(3)$ \\
\hline $\mathrm{Fe}$ & 129.587 & $4079.00(4)$ & $10.22(60$ & 59.57 & $102.88(2)$ & $23.50(5)$ \\
\hline $\mathrm{Zn}$ & 239.94 & $4231.24(5)$ & $1.69(1)$ & 393.43 & $2084.70(3)$ & $119.65(6)$ \\
\hline $\mathrm{Ca}$ & 2058.752 & $10824.83(2)$ & $401.97(6)$ & 3340.54 & $7913.20(3)$ & $915.80(6)$ \\
\hline $\mathrm{Mg}$ & 514.94 & $2073.44(2)$ & $40.86(1)$ & 646.34 & $1546.73(4)$ & $138.36(1)$ \\
\hline $\mathrm{Al}$ & 32.807 & $672.07(2)$ & $0.08(2)$ & 29.58 & $52.50(1)$ & $11.76(50$ \\
\hline $\mathrm{As}$ & 0.0788 & $0.53(2)$ & $0.00(2,3)$ & 0.88 & $0.22(1)$ & $0.04(5)$ \\
\hline $\mathrm{Co}$ & 0.05 & $0.85(2)$ & $0.00(2,3)$ & 0.14 & $0.62(3)$ & $0.01(6)$ \\
\hline
\end{tabular}

From the table 8 , in general most values of metals analyzed showed higher level than international stander values. In addition, mercury in samples of 2010 is very high compared with 2009 and both of them appear in Group 3 (20-29 years old), even though both values above the toxic level. In case of lead, the mean value and the maximum level in both samples for 2009 and 2010 are higher than the international values, which means the pollution with lead is very serious, and may be caused to so many disorder in kidneys, liver and neurological means. Also the Fe is very high more than normal limit in both samples. $\mathrm{Zn}$ also shows high level compared with normal limit in both samples. The other metals measured does not show big fluctuation compared with normal level.

\section{Discussion}

The high level of heavy metals in most parameters measured in this study (table 2)was compared with that of international standard by biomedical lab London, revealed that the high contamination levels in the area that was examined because the people from this area are consuming water from shatt Al- Arab and Tigris rivers, and also are consuming animalian food, that contend heavy metals. (Keskinken et al. 2004). The mean values in this study for $\mathrm{Hg}, \mathrm{Pb}$ and $\mathrm{Cd}$, are lower than other studies carried out in Basrah (Safwan and Al zubair) Karabedian, et.al. (2009). The maximum reading of this study was inconsistent with other studies carried in same area regarding the age group, 10- 20 years old (Al-Imarah ,et.al. 2007). These areas were exposed to many types of weapons of mass destruction during the first and second gulf war. The projectiles were made of many types of heavy metals such as mercury, Uranium, lead and cadmium. Also, it has been reported by other workers, that the natural water contains many pollutant substances in high concentrations (Al-Imarah et. al.,2010). As a result of the exposure of these areas to weapons of mass destruction, heavy metals precipitated deeply in the soil and water. This water was used in the irrigation and dinking. In addition to the post war pollutant metals, the waste products of oil and paper mills that resulted from mercury and heavy metals processing such as $\mathrm{Pb}$ and $\mathrm{Cd}$ which are disposed in the Tigris and Euphrates rivers. All these heavy metals have direct environmental effects on the ecosystem in these areas and causes health threats for the peoples that are using water, as well as fish that live in the river. Pesticides and chlorine industries are another source of heavy metals that are released in the atmosphere (Al- Imarah, et. al. 2003 ; De Prisco, et. al. 2010; Dickman, et.al. 1999; and Srogi, 2004). The maximum levels in most parameters measured were recorded at age 10- 20 years old (group 2) in both samples that were analyzed in the year 2009 and 2010. These values are in consistent with studies by NNorom, et. al. 2005; Dickman, et. al. 1999 and De Prisco , et. al. 2010 ; but disagree with karabedian, et. al. 2009. Heavy metals toxicity can causes damaged and reduced mental control of nervous function, lower energy levels, and damage to blood composition, lungs, kidneys, liver, and other vital organs. Long term exposure may result in slow progressive process that mimic Al-Zhaimers disease, muscular dystrophy and multiple sclerosis ( Khudzari,et.al. 2011). The high level in the heavy and trace metals measured in this study was compared with the Biolab medical lab- London (2010). The high levels of trace and heavy metals may be related to greater absorption of elements in historical populations and resulted in accumulation of heavy metals inside the body, came from diet composed of animally or vegetarian diet and water drink ( Srogi, 2004; Suzuki, et al. 1984; Salman, 2011). The pollution with heavy metals have increased during the period of post first and second gulf war due to the uses of heavy casualty of projectiles. In addition, untreated waste products released from oil refineries and the disposed sewages in rivers and the uses of pesticides in agricultural farms (Al-Imarah et.al 2010; Al-Imarah , et al 2003; Salman,2011). All these waste products contain large amounts of pollutant elements. 
From the previous studies (Al-Imarah, et al. 2010), and this study, results have showed that the high level of mercury and the other most heavy metal appeared at age group 30 -39 year followed by 20- 29 years are inconsistent with other studies. This result suggested that the increase exposure to polluted environment with metals caused increased concentration of metals in tissues including hair (Srogi 2004,; Khudzari et. al. 2011; NNorom, et.al 2005; ). Uranium also appeared in high concentration and show age group dependent in this study. The mean levels of trace elements measured in this study, including $\mathrm{Zn}, \mathrm{Cu}, \mathrm{Fe}$, As, and $\mathrm{Co}$ are inconsistent with other studies (Lyengar and Walttlez 1988; De-Prisco, et.al. 2010).It is important to mention that the trace elements such as $\mathrm{Zn}, \mathrm{Cu}, \mathrm{Fe}, \mathrm{Ca}, \mathrm{Mg}$ and $\mathrm{Co}$ are of great nutritional important for body metabolic processes. These elements obtained in this study have been compared with those available in literatures, showed a similarity and to some extent differences in the mineralogical profiles with our study, due to individual variation. We must remember that some nutritional elements such $\mathrm{Zn}$ and $\mathrm{Cu}$ are chemically competitive with the xenobiotic ones and they exist inside beings to help protect them from the effects of toxic metals (Khalique et. Al.2005). Calcium is very important ion in blood coagulation, muscular contraction, nervous transmission, and in bone formation. In addition, calcium also affects PTH secretion, and other vital activities, which makes it an essential element in adolescent growth and development (Koziecle, et.al.1996). Magnesium has an important role in many cellular functions. It is involved in almost three hundred enzymatic reactions, to be more specific, it is involved in the adenylate cyclase and exokinase enzymes, which are related to physiological condition of human hair(De-Prisco, et. al. 2010). It needs a high daily intake of nearly $320 \mathrm{mg}$ to cover the daily metabolic processes. The magnesium level in this study is inconsistent with other studies (Salman 2011). Iron is also important in vital processes occurred in body especially in $\mathrm{Hb}$ and of numerous enzymes. The level of Iron observed in this study is similar to that of other study carried out in the area (Al-Imarah et. al.2010; Srogi 2004).Cobalt concentration does not show a big (difference when) compared with other studies. Co is a very important element in the status of B12 (De-Prsico et al 2010). Arsenic and Aluminum are toxic metals also showed normal concentration, but still are toxic elements. The sources of these metals possibly from the polluted water drink and ground water used in the irrigation of agricultural fields.(Al-Imarah et.at 2007; Salman 2011).

\section{Conclusions}

The global Environmental monitoring System of the United Nation Environment Program, select human hair as one of the important monitoring materials for worldwide Biological monitoring of pollution (Srogi, 2004; De-Prsico, et al.2010; Dickman et.al 1999).The study recorded high levels of toxic and heavy metals such as $\mathrm{Hg}, \mathrm{Pb}, \mathrm{As}, \mathrm{AL}, \mathrm{U}$, and $\mathrm{Cd}$. In addition to the essential trace elements measured, revealed to the high concentration of pollutant metals that accumulated from waste product from materials used in war and oil, sewages discharges, pesticides used etc. From the previous studies, these heavy metals are mostly toxic and carcinogenic and have many effects on general health. The negative effects include kidney failure, liver dysfunction, blood composition, hormones stability, infertility in both males and females and autism. In order to determine the root causes of these negative health outcomes that were observed in Basrah city, an extensive collaborative series of studies between clinicians and researchers are needed.

\section{References}

Al-Imarah,F.J.M.; Abdul-Hussain,A.S.; and Al-Salman Al-Mayah, Q.M (2010) Toxic environmental paqrameter in water samples from some aquatic Wetland southern Iraq. Basrah J. of Scie. Vol. 28 (2) 253- 261.

Al-Imarah,F.J.; Jawad,A.H. and Kevork,S.A. (2007): Level of mercury in ground water at Zubair and Safwan, south of Iraq . Basrah, proceeding of the $1^{\text {st }}$ Scientific Conferences for College of Sci. ,Al-Muthanna Univ. 9- 10 -12- 2007.

Al-Imarah, F.J.M.; Irabii, D.S and Mohood, AA (2003). Level of mercury in the water and sediments of southern part of Iraq. J.J. Applied scie. 5 : (1), 85- 97.

Amortey, E.O. ; Asumada-Saky,AB.; Quashie,,F.K. ; Duodu,G.O. and Bentil, N.O. (2011). Determination of heavy metals concentration in hair Pamades on the Ghanaian Market using Atomic absorption A spectrophotometry technique . Br. J. of Pharmacol. \& Toxicol. 2 (4) : 192 -- 198

ATSDR " Agency for Toxic Substance and Disease Registry" ( 2007): Toxicological profile for lead, $\mathrm{U}$, department of health and human service. Public Health Humans Services Centers for Disease control; Atlanta. 
ATSDR " Agency for Toxic Substance and Disease Registry" ( 2008): Draft toxicological profile for cadmium, Us department of health and human services. Public Health Humans Services Centers for Disease control; Atlanta

Biolab Medical Unit London, (2010): Hair mineral analysis Nutritional and environmental medicine London, England. Retrieved from :www. Biolab.co.uk.

Christopherer, M.M.; koller,C.E.; Rodger,J.C.; and Macfarlane, G.R.(2009). Mammalian Hair as an accumulative bio indicator of metal bioavailability in Australian terrestrial environment. Scie.of the Total Environ. 407 : 3588 - 3596.

Chlopicka, J.; Zachmieja,Z.; Zagrodezki, P.; Frydryob,J.; Salota,P. and Krosniak,M (1998): Lead and cadmium in the hair and blood children from high industrial area in Poland. Biol. Trace Elem. Res. 62, 229-234.

Davies, S. (1982). Hair analysis and selenium shampoo. Lancet 11, PP 935.

De-Prisco,P.P.; Volpe, M. G.; Petitto, F.; Palladino,C. ; Capasso,A. ; Di-Stasio, M. and De Prisco,R. (2010). Level of essential and toxic metals in urban adolescents hair : Preliminary study. Biomed. Res., 21 (2): 131- 141.

Dickman, M.D.; Leugn, K.M.C. and Koos, L.C.L. (1999). Mercury in human hair and fish: is there a Hong Kong male subfertility connection?. Mari. Poll. Bull. Vol. 39 :No. 1-12 pp.352- 356.

Duruibe, JO. ; Ogwueghu, MOC. And Egwurugwu, JN.( 2007). Heavy metals pollution and human biotoxic effects. Int. J. Phys. Sci. 2 (5): 112118.

Erten, J.; Arcasory, A. and Cavdar, AO. (1978). Hair Zinc level in health and malnourished children . Am. J. Clin. Nauttr. $31: 1172-1174$.

Fido,A. and Al-Saad,S. ( 2005). Toxic trace elements in hair of children with autism. Autism. 9290 298.

Harkins,D.K. and Susten, A.S. (2003). Hair analysis: Exploring the state of the science. Environ. Health Perspec. 111 pp 576-578.

Hassan, I. ; Afridi- Gazi, T.G. ; Jamali,M.K. ; Kazi, G.H.; Araia, M.B.; Jalbani, N. ; Shar,G.Q. and Sarfaraz, A.R. (2006).Evaluation of toxic metals in biological samples (scalp hair, blood and urine) of steel mill workers by ectothermic atomic absorption spectrometry. Toxicol. Ind. Health. 22; pp 381 -
IAEA(International Atomic Energy Agency) (1994) ;Application of hair as an indicator for trace element. Exposure in man Nah Res. 22:IAEA

Karabedian, S; Al-Imarah,F.J.M. and Ibraheem,H.K ( 2009).Determination of Mercury in hair samples of Iraqis population living in Safwan and AlZubair Southern Basrah . J. Duhok Univ. Vol. 12 , (Special issue ). PP. 23- 27.

Keskinkan,O. ;Goksu, M.Z. L. ; Basibuyuk, M. and Forster, C.F. ( 2004). Heavy metals adsorption properties of submerged aquatic plant ( Ceratophyllum demersum). Bio resources Technol. $19: 197-200$.

Khalifi,R. and Hamza-Chaffai,A. (2010). Head and neck cancer due to heavy metals exposure via tobacco smoking and professional exposure. Rev. Toxicol. and Appl. Pharmacol. .248 : 7188.

Khlique, A.; Ahmad, S. ; Anjum,T.; Jaffar,M.; Munir,Shah, H. ; Shaheen,N.; Saadia,TR. And Manzoor,SA. (2005). Comparative study based on gender and age dependenceof selected metals in scalp hair . Environ. Monit. and Assess. 104 (1-3) . pp $45-57$.

Koziecle,T. ; Drybanska- Kalita,A.; Hormowska I. and Salacka A. (1996). Level of calcium, Magnesium, Zinc, copper and iron in hair of children and adolescents. Pol. Merkuriusz Lek 1 (2) : $150-154$.

Khudazari, J.; Wagiran, H.; Imam Hussain; Ibrahim, N. and Agam, A. (2011). Heavy metals Mn, Ni, Cu, and $\mathrm{Zn}$ in human hair samples using energy dispersive X-ray fluorescence. Int. J. of Phy. Sci. Vol.6 (8) pp 2090 - 2094.

Lyangar,V. and Wolttlez, J. (1988). Trace elements in human clinical specimens : Evaluation of literature data to identify reference values. Clin.Chem. 34/3. 474- 481.

Majewska, M. D.; Urbanowicz, E.; Rok-Bujko,P.; Namyslowska,I. and Mierzeejewski, J. (2010).Age dependent lower or higher level of mercury in autistic children than in healthy control. Acta Neurobiol. Exp. 70 pp 196-208.

Ming-Ho,H. (2005). Environmental toxicology; Biological and health effects of pollutants. Chap.12 CRC Press. LLC, 15BN1-56670- 6702. $2^{\text {nd }}$ Edition, Boca Raton, USA.

Morais,S. ; Garcic eCasta, F. and Pereira, M.L. ( 2011). Heavy metals and human health : Environ. health- Emerging Issues and Practice 425- 445 
NNorom,I.C. ; Igwe, J.C. and Ejimone, J.C. (2005).Multielements analysis of human scalpel hair samples from three distant towns in southeastern Nigeria. J. African J. of Biotechnol. Vol. 4 pp.1124-1127.

Per-eiraab. R.; Ribeir, ocR. And Gonc, F. (2004). Scalp hair analysis as a tool in assessing human exposure to heavy metals (SD omingos mine Portugal). Sci. of the Total Environ. 327 : pp 8192.

Salman, N.A. (2011). Assessment of environmental toxicity in Iraqi southern marshes using fish as Bio-indicators. Ekologija, T.57 Nr. I.P. 21-29.

Srogi,K. ( 2004). Heavy metals in human hair samples from Silesia Province; influence of sex, age and smoking habit. Problems of Forensic Sciences vol.1X : 7- 27.

Suzuki T.; Hongo T. ; Morita M. (et.al.) (1984). Elemental contaminationof Japanese womens hair from historical samples. Sci. of the total environ. Vol 99 : $81-91$. 